\title{
Assessment of production eco-system services of the salted and solonetzic soils of South of Ukraine
}

Baliuk S. ${ }^{1}$, Drozd O. ${ }^{2}$

NSC "A.N.Sokolovsky Institute of soil science and agrochemistry», Chaikovska Str., 4, Kharkiv, 61024,

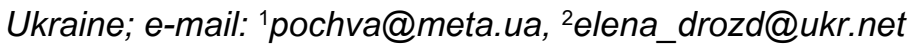

The purpose. To develop system of assessment of production eco-system services of the salted and solonetzic soils of South of Ukraine. Methods. Field, laboratory probes, systems analysis. Results. South chernozems of different extent of natural and irrigational salinization and alkalinity within the limits of Ingulets irrigation system (Kherson and Mykolaiv oblasts, South of Ukraine) are studied with the purpose to develop the system of assessment of production eco-system services of saline lands of Ukraine. The algorithm of assessment of production eco-system services of saline lands of Ukraine is also offered. It includes soil-reclamative inspection, assessment of contemporary ecological-and-agromelioration state of lands, assessment of receptivity of eco-system services to different types of amelioration. It is fixed the following: ecological-and-agromelioration state of the majority of rain-fed lands is satisfactory; state of soils sewaged by sprinkling irrigation and inferred from irrigating - good and satisfactory depending on the level of occurrence and mineralization of soil waters; state of soils sewaged by dropping unsatisfactory. The 10-mark rating scale for production eco-system services of the salted and solonetzic soils with application of methods of digital cartography is offered. Assessment of the level of production eco-system services according to the offered method showed that there were no plots with good level of production eco-system services, 14 plots had satisfactory level, and 1 - unsatisfactory. Unsatisfactory level of production eco-system services was caused by mainly close levels of occurrence of soil waters. Conclusions. The offered methodical approach opens opportunities of more complete use of potential of production functions of saline lands by differentiation of reclamative loads and their adaptation to operation of biological systems.

Key words: soils, salinization, alkalinity, ecological-and-agromelioration state, production eco-system services, assessment.

https://doi.org/10.31073/agrovisnyk201901-09

Program goals of sustainable development for the period till 2030, adopted September 15, 2015 the UN member countries, is to overcome the food crisis in the world, responding to climate change and sustainable management of natural resources [1]. Recognition of the central role of soil resources in ensuring food security and awareness of the fundamental role of soils in adapting to climate change and biodiversity conservation has made the soil one of the most important priorities and necessitates changes to existing agricultural practices [1-3]. Environmentally sound land use, based primarily on the ability of the soil to maintain its ecological functions outside the external influence of anthropogenic factors, is an integral part of sustainable development. Therefore, to ensure high productivity, management of soil resources should be based on sustainability and ecosystem approach [3].

Issues of ecosystem services of soils, including various types of their assessment, are actively explored in the world $[4-8,16]$. Ecosystem services - are the multitude of benefits that nature provides to society. There are provisioning services, supporting services, regulating services and cultural services. The World Soil Charter states that the use of soils is rational if all ecosystem services provided by the soil are maintained or improved without significant deterioration of the soil functions that make such services possible [3]. The assessment of ecosystem services is intended to assess the impact of ecosystem changes on human well-being and to scientifically justify the measures needed to improve the quality of 
the environment, the sustainable use of ecosystems and sustainable development. Practical accounting of ecosystem services is carried out in many countries of the world. The leaders are the EU countries, for many of which the ecosystem services were assessed at the national level.

Every year, it is growing Ukraine's role as an agrarian country in ensuring food security of Europe and the world. Ukraine is one of the most agriculturally developed countries in the world. As of January 1 , 2017, the land fund of Ukraine is 60.3 million hectares, or about 6 percent of the territory of Europe. Agricultural lands are about 19 percent of the European ones, including arable land - about 27 percent. Indicator of agricultural land per capita is the highest among European countries and is 0.9 hectares, including 0.7 hectares of arable land (the average European countries - 0.44 and 0.25 hectares, respectively). The total area of agricultural land is 42.7 million hectares, or 70 percent of the total area of the country, and the area of arable land - 32.5 million hectares, or 78.4 percent of all agricultural land [8]. At the same time, in the structure of land resources of the country and land use there are significant disproportions, the deepening of which can be a threat to the environment and living environment, as well as the effectiveness of economic activity, sustainable development of the national economy as a whole [10].

More than half of the territory of Ukraine is in zones of insufficient and unstable moisture, in addition to it there are the prolonged periods of droughts, therefore, the production and resource supply of the country, as well as many countries of the world, depends on the state and efficiency of the use of the soil of the reclamation fund. One of the most serious manifestations of soil degradation in the zone of insufficient and unstable moisture is soil salinization [10, 11, 12].

Reclamation of saline soils is part of a unified system of interconnected techniques for the management of the fertility of saline soils. At the same time, the use of any soil fertility management measures is interference in the natural soil-forming process and, as a consequence, there are changes in the ecosystem services of the soil. These changes can be both positive and negative, causing varying degrees of stability and adaptation of the ecosystem to the new conditions of operation.

In view of the growing environmental risks associated with climate change (land degradation and desertification), it is increasing the recognition that land use and land use management is to maintain the multifunctionality of natural and managed ecosystem services of saline lands due to the use of balanced reclamation loads. It will allow to plan and implement ecologically and economically friendly, adapted to changing soil-climatic and social conditions, principles and technological solutions aimed at the sustainable management of saline soils.

The purpose - to develop a system for evaluating productive ecosystem services of saline and solonetz soils in the south of Ukraine.

Research methodology. The estimation of ecosystem services of saline soils of Ukraine was carried out during 2016-2017 for pilot areas of one of the largest irrigation systems in Ukraine - the Ingulets irrigation system. The soil cover of the Ingulets irrigated array is represented, in the first place, by chernozemic and dark chestnut soils of different granulometric composition and different degrees of natural and anthropogenic (due to irrigation) salinization and alkalization [14].

On the basis of the analysis of space images, aerial photography, cartographic information, literary sources, and preliminary research results, 15 pilot areas. The pilot areas included unirrigated (control), irrigated and removed from irrigation land areas: 12 with the level of underground waters of 1-3 meters, and 3 with groundwater level more than 5 meters. 
A comparative study of soil properties, the establishment of regularities of processes in re-claimed and non-reclaimed saline soils, and the establishment of the sensitivity of ecosystem services to ameliorative effects was carried out on analogues in the conditions of long-term stationary experiments. Investigated meliorative measures: chemical methods for improving the quality of irrigation water, chemical soil reclamation (different doses of phosphogypsum), reclamation plantag plowing at a depth of 60-65 cm.

Chemical analyses of soil samples, irrigation and groundwater, plants and estimation of ecological and agro-ameliorative status were held in certified laboratories National Scientific Center «Institute for Soil Science and Agrochemistry Research named after O.N. Sokolovsky" under the current regulatory framework in Ukraine.

Results. The analysis of the selected samples of irrigation water showed that the total mineralization was within the range of $0.9-1.9 \mathrm{~g} / \mathrm{dm}^{3}, \mathrm{pH}$ within the neutral range (6.9-7.4), and the type of salts was sulfate-non-chloride magnesium-sodium. Irrigation estimation according to NSSU 2730 and 7286 showed that mostly corresponded to the 2 nd class (limited for the purpose irrigation) due to the threat of salinization and the 1 st class (suitable for irrigation) for the threat of splitting.

Soils within the pilot territories on non-irrigated areas are characterized by depth of occurrence of subsoil waters of 4.0-5.0 meters, areas irrigated by the method of sprinkling - 3.0-3.5 meters, removed from irrigation areas - 2.0-3.5 meters, the areas irrigated by the droplet method - 1 - 2 meters. The chemical composition of groundwater is sulfate magnesium-sodium or sodium-magnesium, mineralization $-1,9-3,1 \mathrm{~g} / \mathrm{dm}^{3}$ (weakly mineralized).

The soils of non-irrigated control sites were unreacted (the content of toxic salts is $0.05-0.08 \%$ ). The weak degree of salinity of chernozems in the south was observed predominantly in the areas of application of drip irrigation, separate irrigated by irrigation (content of toxic salts in a layer of $0-100 \mathrm{~cm}$ $0.15-0.18 \%$ ) and removed from irrigation areas (the content of toxic salts in the layer $0-100 \mathrm{~cm} 0.23 \%$ ).

The total irrigation and natural salinity of soils of a weak degree were observed mainly in a layer of 0-50 cm only of irrigated by various methods (sprinklers and drip irrigation) and soils removed from irrigation and was due to a significant extent to the content of the collected potassium, which naturally occurs in soils of the region. These soils also have agrophysical features of solonocytes (formation and shivering of structural macroaggregates). Halo salinity and salinity are dynamic and depend on the hydrogeological and reclamation conditions of the territory in different years.

The total humus content in the arable layers of all soils in the zone of the Ingulets channel varies within the range of 2.6-3.8\%, which corresponds to the medium and higher degree of humus content. No significant changes in humus content depending on the ameliorative effects on stage research have been identified. The content of mineral nitrogen in soils fluctuated at the level of medium and low levels of security. The availability of mobile forms of phosphorus is mainly elevated and high, sometimes average. The availability of mobile forms of potassium is very high in soils of all pilot territories (NSSU 4362). Soils at a depth of $0-50 \mathrm{~cm}$ are not contaminated with heavy metals.

The ecological and agro-ameliorative status of irrigated lands and lands which were no longer irrigated, a level of underground water deeper than $5 \mathrm{~m}$ should be considered as "good", levels of underground water between 3.5 and $4 \mathrm{~m}$ as satisfactory. For the ecological and agro-ameliorative status of the lands removed from irrigation, the level of underground water was $2-3 \mathrm{~m}$ in pilot areas, which is considered unsatisfactory. Such an estimate is due to the availability of weak salinity, the danger of further irrigation salinization and alkalinity of the southern chernozems due to the possibility of raising 
mineralized groundwater to critical levels, especially if irrigation is restored with II class water, the average content of organic matter and mineral nitrogen and available phosphorus, which is insufficient for maximum realization of the potential of productivity of agricultural crops. The ecological and agroameliorative state of the irrigated land by droplets is assessed as unsatisfactory, since significant danger is the level of occurrence of groundwater, which is close to critical, which causes periodic flooding of soils. Under such hydrogeological conditions, groundwater directly influences the soil profile, changing its morphology. There are intensive gelling processes, as well as in the case of mineralization of subsoil and irrigation water, salinity and alkalinity, which are on the studied lands. At the same time, the thermal, water, gas, biological and nutrient regimes of soils are violated; the compounds recover iron compounds, manganese, sulfur and other elements, which accumulate in the profiles. The productivity potential of agricultural crops cannot be realized.

The use of chemical melioration of irrigation water, irrigated soils, a complex of measures, reclamation plowing provided the increase in crop yields compared with non-melioration options. Efficiency of melioration measures and their aftereffects increases in combination with other agrotechnical measures. The most prolonged effect on crop yields has ameliorative plowing. The longest aftereffect on the crops yield is ameliorative plowing (up to $30 \%$ in non-irrigated conditions and up to $50 \%$ in irrigated, the duration of the after-effect is more than 50 years). Comparison of meliorative effects and duration of aftereffects showed their increase in the following order: chemical reclamation of irrigation water, chemical land reclamation and ameliorative plowing [10, 13-15].

Estimation of ecosystem services of saline soils (chernozems of southern and dark chestnut soils) by their reclamation in the conditions of southern Ukraine according to the results of our research we propose to conduct on the 10-point scale on the set of indicators, shown in Table. 1. Parameters of indicators for Provisioning ecosystem services include three gradations according to the levels of their provision: 1) good (10 points), 2) satisfactory (5 points), 3) unsatisfactory (0 points).

Table 1. - Indicators of evaluation of the Provisioning ecosystem services of saline reclaimed soils in the south of Ukraine and their parameters

\begin{tabular}{|l|l|l|l|}
\hline \multirow{2}{*}{ Evaluation Indicator } & \multicolumn{3}{|l|}{ Level of service delivery, its evaluation in points } \\
\cline { 2 - 4 } & $\begin{array}{l}\text { Good } \\
10 \text { points }\end{array}$ & $\begin{array}{l}\text { Satisfactory } \\
5 \text { points }\end{array}$ & $\begin{array}{l}\text { Unsatisfactory } \\
0 \text { points }\end{array}$ \\
\hline $\begin{array}{l}\text { Quality of irrigation water according to } \\
\text { agronomic criteria }\end{array}$ & I class & II class & Ill class \\
\hline $\begin{array}{l}\text { Average for the vegetation period depth of } \\
\text { underground water level, } \mathrm{m}\end{array}$ & $\begin{array}{l}\text { More than } \\
5\end{array}$ & critical - 5 & Less critical \\
\hline Mineralization of underground water, g/dm3 & - & Less than 3 & More than 3 \\
\hline $\begin{array}{l}\text { Degree of salinization of soil, layer } 0- \\
100 \mathrm{~cm}\end{array}$ & Absent & weak & medium, strong \\
\hline Degree of alkalinity of soil, layer $0-30 \mathrm{~cm}$ & Absent & weak & medium, strong \\
\hline $\begin{array}{l}\text { Level of content of nitrate and ammonium } \\
\text { nitrogen, layer } 0-50 \mathrm{~cm}\end{array}$ & High & medium, increased & Very low, low \\
\hline $\begin{array}{l}\text { Level of content of available phosphorus, } \\
\text { layer } 0-30 \mathrm{~cm}\end{array}$ & High & $\begin{array}{l}\text { medium, increased, } \\
\text { very high }\end{array}$ & Very low, low \\
\hline $\begin{array}{l}\text { Level of content of potassium exchange, a } \\
\text { layer } 0-30 \mathrm{~cm}\end{array}$ & High & medium, increased & $\begin{array}{l}\text { Very low, low, very } \\
\text { high }\end{array}$ \\
\hline
\end{tabular}


Application by irrigation of waters of class 1 is estimated at 10 points, because by using for irrigation of such waters $[10,16]$ for a high culture of agriculture, the application of a scientifically sound fertilizer system involves the cultivation of soils and the formation of highly productive agrocenoses. By applying for irrigation of water of the 2nd and 3rd classes (limited and unsuitable for agronomic and ecological criteria), a number of soil-degradation processes (salinization, alkalinity, degradation, dispersion, dehumidification, depletion on nutrient elements, contamination of toxicants, inhibition and change in the species composition of the microbocenoses, etc.) initially in the weak, and for prolonged irrigation - in medium and in strong stages. Under such conditions, degradation changes accumulate in the soil profile and cause the impossibility of full reproduction of soil fertility resources, cause to a progressive decline in yields. Accordingly, they are scored at 5 and 0 points.

Hydrogeological indicators 2 and 3 are interrelated. By the depths of occurrence of underground water more than 5 meters they do not affect the soil profile, therefore, in any of their mineralization, both indicators are estimated at 10 points. By depths of underground waters from the critical to 5 meters, they to some extent periodically affect the lower part of the soil profile due to capillary rise, which can cause the development of such negative processes as gelling and salinization to a weak degree, which reduces the assessment of these indicators to 5 points.

If at the same time the mineralization of underground water exceeds $3 \mathrm{~g} / \mathrm{dm}^{3}$, then the salinity of the subsoil can be reduced to a medium degree, which reduces the estimation of the indicator "mineralization of underground water" to 0 points. By the depth of underground waters, less critical, they regularly intensively influence the soil profile, which causes intensive development of gleying process, creates extremely unfavorable conditions for the growth and development of cultivated plants due to deterioration of water, gas, nutrient and biological regimes and reduces the estimation of both indicators to 0 points irrespective of the mineralization of groundwater.

The degree of salinization of the soil (layer 0-100 cm) and the degree of soil salinity (layer 0-30 cm) determine a number of other interconnected properties (agrophysical, physico-chemical, etc.), which affects the degree of implementation of soils Provisioning ecosystem services. The increase in the degree of manifestation of these processes increases their negative impact on soil properties. The presence of medium and high salinity and alkalinity of soils causes the estimation of this indicator to 0 points.

The content of nutrients is evaluated according to the levels of their provision in accordance with the existing normative base in Ukraine. The "very high" content of available phosphorus (layer 0-30 cm) is proposed to be evaluated at 5 points, since such content for cultivated plants is not optimal and can cause some damage. The "very high" level of exchangeable potassium content is proposed to be evaluated at 0 points, since potassium is a saltinating cation and, under irrigation, is limited by the risk of water solubilization, it can lead to a deterioration of a number of soil conditions and properties.

A generalized assessment of the Provisioning ecosystem services is proposed using the formula:

$\mathrm{n}$

$E=\sum e: n$

1

where

E - generalized assessment of Provisioning ecosystem services on saline reclaimed soils of southern Ukraine, points;

e - estimation of a separate indicator, points;

$\mathrm{n}$ - number of indicators (in our case, 8).

For a general assessment of the provision ecosystem services, the following gradation of its levels is proposed:

- unsatisfactory - from 0 to 4 points (production reduction more than $30 \%$ of the planned);

- satisfactory - from 4,1 to 7 points (production reduction more than $30 \%$ of the planned);

- good - from 7,1 to 10 points (yield at planned level). 
A mapping method was used to assess the Provisioning soil ecosystem services. At the same time, the developed series of maps was used according to the indicators of the ecological-agromeliorative state of the soil of the pilot areas. The sets of vector objects (polygons) obtained as a result of digitization were laid down in the new overlay analysis carried out by imposing polygons on the pilot areas as a result of the study and the association of their attribute data (Figure 1). The analysis was performed using the Intersect tool from the Spatial Analyst module in ArcGIS 10.2. Each explored area was divided into polygons, for each of them the combined attributive data (level and mineralization of fresh water, degree of salinity, degree of alkalinity, etc.) were obtained.

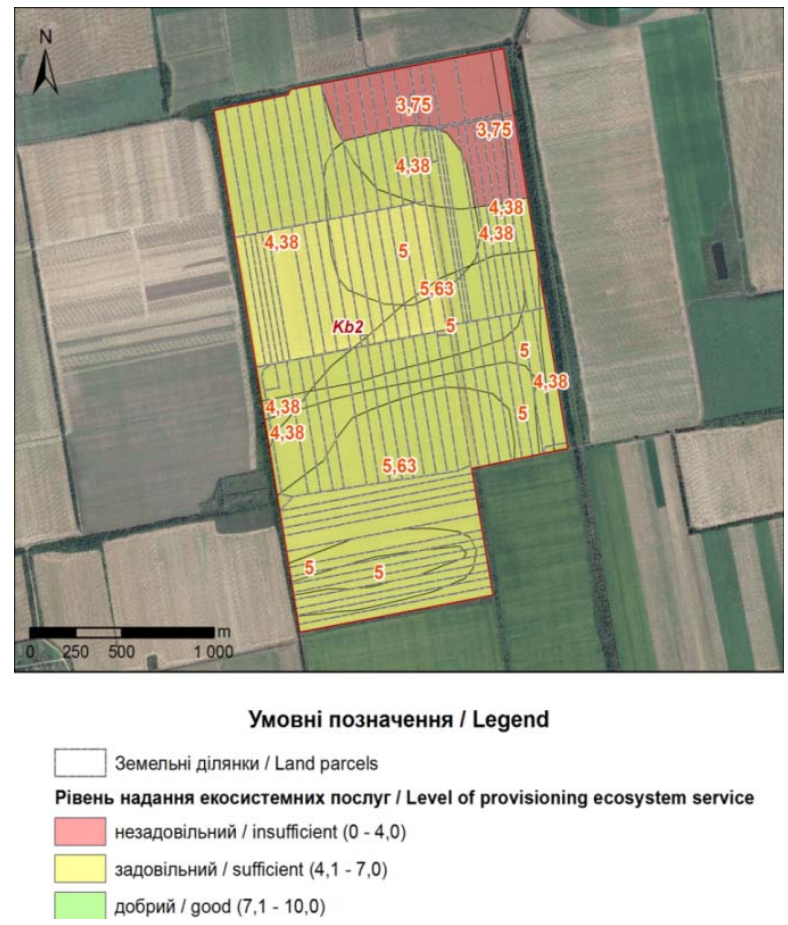

Figure 1. The result of the integration of the mapping scheme of the Provisioning soil ecosystem function of the pilot areas (sprinkling) with the data of the cadastral map.

We gave a point assessment for the Provisioning ecosystem services for 15 pilot sites within the Ingulets Irrigation System. It was determined that there are no sites with a good level; 14 sites are satisfactory and 1- unsatisfactory. The unsatisfactory level of supply of ecosystem services was due to predominantly near levels of underground water.

Conclusions. The system of estimation of the production ecosystem services of saline and saline soils of the south of Ukraine is proposed, which is based on the results of determination of the ecological and agro-amelioration status of the territories of pilot territories and the susceptibility of ecosystem services of saline and saline soils to various types of melioration. According to the results of our research, we propose to evaluate the production of ecosystem services of soils of saline soils and saline soils in the south of Ukraine, according to the results of our research, on a 10-point scale of 8 indicators. The parameters of the indicators include three gradations according to the levels of their provision: good (10 points), satisfactory (5 points), unsatisfactory (0 points). The evaluation is carried out using digital mapping techniques.

Comparison kartoshem levels of productive ecosystem services saline soils pilot areas of the cadastral map data can recommend ways adaptive landscape irrigation, optimum mechanisms regulating the use of soil in pilot areas for individual land users and enterprises of different forms. The application of 
the proposed system allows us to more fully utilize the potential and production functions of saline soils in Ukraine by differentiating land reclamation loads as the basis of sustainable management of soil resources and environmental protection at both local and national levels.

\section{Reference}

1. Food and Agriculture.. Key to achieving the 2030 Agenda for Sustainable Development. Rome: Food and Agriculture Organization of the United Nations, 2015. 50 p. [in Russian].

2. Voluntary Guidelines for Sustainable Soil Management. Rome : Food and agriculture organization of the United Nations, 2017. $18 \mathrm{p}$.

3. World Soil Charter. Rome: Food and Agriculture Organization of the United Nations, 2015. 17 p. [in Russian].

4. Konyushkov D. E. (2015). Formirovanie i razvitie kontseptsii ekosistemnyih uslug: obzor zarubezhnyih publikatsiy. Byulleten Pochvennogo instituta im. V.V. Dokuchaeva. Vyip. 80. P. 26-49. [in Russian].

5. Fisher B., Turner R.K., Morling P. (2009). Defining and classifying ecosystem services for decision making. Ecological Economics. № 68(3). P. 643-653.

6. Lehmann A., David S., Stahr K. (2008). TUSEC - Handbuchzur Bewertung von natürlichen Böden und anthropogenen Stadtböden. Hohenheimer Bodenkundliche Hefte, $224 \mathrm{p}$.

7. MEA (Millennium Ecosystem Assessment). Ecosystems and Human Well-Being: Synthesis. Washington: Island Press. 2005. 155 p.

8. Ekosistemnyie uslugi nazemnyih ekosistem Rossii: pervyie shagi. Status Quo Report. Moskva: Tsentr ohranyi dikoy prirodyi, 2013. 45 p. [in Russian].

9. Balyuk S.A., Medvedev V.V., Mlroshnichenko M.M. (Eds.). Kontseptsiya dosyagnennya neytralnogo rlvnya degradatsIYi zemel (Gruntlv) v Ukrayini. Harklv,2018. 30 p. [in Ukrainian].

10. Balyuk S.A., Romaschenko M.I., Truskavetskyi R.S. (2015). Melioratsiya gruntiv (sistematika, perspektivi, InnovatsIYi): kolektivna monograflya. Herson: GrIn D.S., 2015. 668 p. [in Ukrainian].

11. BaliukS., Drozd E., Zakharova M. (2015). Scientific approaches to the rational use and management of saline soils fertility in Ukraine. Arid Lands Studies (JALS), vol. 25 No. 3. P. 69-72.

12. Vargas R., Pankova E.I., Balyuk S.A., Krasilnikov P.V., Hasanhanova G.M. (2017). Rukovodstvo po upravleniyu zasolennyimi pochvami. Prodovolstvennaya i selskohozyaystvennaya organizatsiya ob'edinYonnyih natsiy. Rim. 146 p. [in Russian].

13. Balyuk S.A., Romaschenko M.I., Stashuk V.A. (Eds.). (2009). Naukovi osnovi ohoroni ta ratsionalnogo vikoristannya zroshuvanih zemel Ukrayini. K.: Agrarna nauka. 620 p. [in Ukrainian].

14. Ushkarenko V.O., Vozhegovoya R.A. (Eds.). (2010). Zemli Inguletskoyi zroshuvalnoyi sistemi: stan ta efektivne vikoristannya. K.: Agrarna nauka. 352 p. [in Ukrainian].

15. Baliuk S.A., Drozd O.M, Gavrilovich N.Yu. (2014). Kompleksna otsInka agrogennih zmln vlastivostey solontsevih Gruntlv Suhogo Stepu UkraYini. Visnik agrarnoyi nauki. 9. P. 44-48. [in Ukrainian].

16. Balyuk S.A., Drozd O.M. (Eds.). (2017). Otsinka ekosistemnih poslug zasolenih gruntiv pid vplivom melioratsiyi (metodichni rekomendatsiyi). Harkiv.: FOP Brovin O. V. 128 p. [in Ukrainian]. 